\title{
Urville-Nacqueville - Le Haut de Nacqueville
}

$\mathrm{n}^{\circ} 3395$

\section{Anthony Lefort}

\section{(2) OpenEdition}

\section{Journals}

Édition électronique

URL : http://journals.openedition.org/adlfi/16808

ISSN : 2114-0502

Éditeur

Ministère de la culture

Référence électronique

Anthony Lefort, «Urville-Nacqueville - Le Haut de Nacqueville », ADLFI. Archéologie de la France Informations [En ligne], Basse-Normandie, mis en ligne le 26 février 2016, consulté le 02 mai 2019. URL : http://journals.openedition.org/adlfi/16808

Ce document a été généré automatiquement le 2 mai 2019.

(C) Ministère de la Culture et de la Communication, CNRS 


\section{Urville-Nacqueville - Le Haut de Nacqueville}

$n^{\circ} 3395$

Anthony Lefort

Lien Atlas (MCC) :

http://atlas.patrimoines.culture.fr/atlas/trunk/index.php?

ap_theme=DOM_2.01.02\&ap_bbox=-1.786;49.649;-1.704;49.680

1 Cette opération de sondages visait à tester le potentiel archéologique du rebord de plateau dominant la plaine maritime d'Urville-Nacqueville, en surplomb du lieu-dit la Valette, et à proximité immédiate du fort de la Batterie Haute. Aucun des sondages pratiqués ne s'est révélé positif, à l'exception d'une petite fosse maçonnée de la Seconde Guerre mondiale.

INDEX

Index chronologique : ép. contemporaine

Index géographique : Basse-Normandie, Manche (50), Urville-Nacqueville (50611)

operation Sondage (SD)

Mots-clés : fosse 


\section{AUTEURS}

\section{ANTHONY LEFORT}

Inrap 